DOI:

\title{
PERTUMBUHAN PADI GOGO LOKAL PADA LAHAN ULTISOL YANG DIBERI BERBAGAI TAKARAN BOKASHI AMPAS SAGU DAN TRICHODERMA
}

\author{
GROWTH OF LOCAL UPLAND RICE ON ULTISOL BY USING DIFFERENT \\ DOSES OF BOKASHI SAGO PULP AND TRICHODERMA
}

\author{
Hadania S. ${ }^{1}$ Sarawa $^{2 *}$ Abdul Madiki $^{2}$ Laode safuan $^{2}$ Andi Nurmas ${ }^{2}$ Rachmawati Hasid $^{2}$ \\ 1. Mahasiswa Jurusan Agronomi Program Pascasarjana Universitas Halu Oleo \\ 2. Dosen Jurusan Agronomi Program Pascasarjana Universitas Halu Oleo
}

Diterima: 25 Maret 2019/Disetujui: 17 Mei 2019

\begin{abstract}
This study aimed to examine the effect of giving bokashi sago pulp and Trichoderma to the growth of local upland rice on ultisol fields. The study was carried out in Experimental Field II Dryland Unit and Agronomy Laboratory of the Faculty of Agriculture, Halu Oleo University Kendari starting from January to August 2018. The study design used a factorial randomized block design (RBD) pattern consisting of two factors. The first factor is the treatment of sago pulp bokashi, namely; BO = without bokashi, B1 = 12 tons ha-1 sago pulp, B2 = 24 tons ha- 1 bokashi sago pulp, B3= 36 tons ha-1 sago pulp and B4 = 48 tons ha-1 bokashi sago pulp. The second factor for the application of Trichoderma, namely; $T 0=$ without Trichoderma, $T 1=1.6$ tons $h-1$ Trichoderma, $T 2=3.2$ tons $h-1$ Trichoderma, T3 = 4.8 tons $h-1$ Trichoderma, T4 = 6.4 tons $h-1$ Trichoderma. Thus there will be 25 combinations of treatments. Each combination of treatments was repeated three times, so there were 75 experimental units. Data from observations on each of the variables observed were analyzed by variance. Further tests using Duncan's multiple distance test (UJBD) at the real level $\alpha=0.05$. The results showed that the best dosage of interaction between bokashi sago pulp and Trichoderma was B3T3 (36 tons ha1 bokashi and 4.8 tons ha-1 Trichoderma).
\end{abstract}

Key words: Bokashi sago pulp, Quality, Local upland rice, Production, Trichoderma

\section{ABSTRAK}

Penelitian ini bertujuan untuk mengkaji pengaruh pemberian bokashi ampas sagu dan Trichoderma terhadap pertumbuhan padi gogo lokal pada lahan ultisol. Penelitian dilaksanakan di Kebun Percobaan II Unit Lahan Kering dan Laboratorium Agronomi Fakultas Pertanian Universitas Halu Oleo Kendari mulai dari bulan Januari sampai Agustus 2018. Rancangan penelitian menggunakan Rancangan Acak Kelompok (RAK) pola faktorial yang terdiri dari dua faktor. Faktor

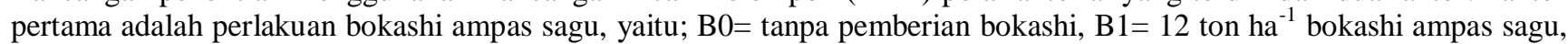
$\mathrm{B} 2=24$ ton $\mathrm{ha}^{-1}$ bokashi ampas sagu, B3= 36 ton $\mathrm{ha}^{-1}$ bokashi ampas sagu dan B4= 48 ton ha ${ }^{-1}$ bokashi ampas sagu. Factor kedua aplikasi Trichoderma, yaitu; $\mathrm{T} 0=$ tanpa Trichoderma, $\mathrm{T} 1=1,6$ ton $\mathrm{h}^{-1}$ Trichoderma, $\mathrm{T} 2=3,2$ ton $\mathrm{h}^{-1}$ Trichoderma, $\mathrm{T} 3=4,8$ ton $\mathrm{h}^{-1}$ Trichoderma, $\mathrm{T} 4=6,4$ ton $\mathrm{h}^{-1}$ Trichoderma. Dengan demikian akan terdapat 25 kombinasi perlakuan. Setiap kombinasi perlakuan diulang sebanyak tiga kali, sehingga terdapat 75 unit percobaan. Data hasil pengamatan terhadap masing-masing variabel yang diamati dianalisis dengan sidik ragam. Uji lanjut menggunakan uji jarak berganda Duncan (UJBD) pada taraf nyata $\alpha=0,05$. Hasil penelitian menunjukkan Dosis terbaik interaksi bokashi ampas sagu dan Trichoderma yaitu B3T3 (36 ton ha ${ }^{-1}$ bokashi dan 4,8 ton ha $^{-1}$ Trichoderma).

Kata Kunci: Bokashi ampas sagu, Kualitas, Padi gogo lokal, Produksi, Trichoderma

\section{PENDAHULUAN}

Padi (Oryza sativa L.) adalah salah satu komuditas tanaman pangan yang sangat penting untuk terus di budidayakan. Hal ini dikarenakan beras sudah menjadi sumber pangan utama yang dikonsumsi oleh hampir seluruh lapisan masyarakat, sehingga permintaan beras terus mengalami peningkatan seiring pertumbuhan jumlah penduduk yang terus bertambah dengan laju peningkatan $2 \%$ per tahun. Beras harus selalu tersedia dalam jumlah yang cukup, berkualitas dan harga terjangkau. Apabila produksi padi terganggu maka akan menimbulkan dampak pada sektor ekonomi dan sosial di masyarakat, seperti tingginya harga beras

\footnotetext{
* Penulis untuk korespondensi,e-mail: sarawa60@yahoo.com
} 
dan terjadinya kerawanan pangan (Wahab, 2014 dalam Usman, 2018).

Pemenuhan ketersediaan beras selama ini banyak berasal dari hasil budidaya padi sawah sementara belakangan terus terjadi fenomena produktivitas padi sawah irigasi yang cenderung turun (Badan Litbang Pertanian, 2008). Terjadinya penurunan hasil produksi padi sawah disebabkan oleh banyak faktor, antara lain perubahan iklim yang tidak menentu, ketersediaan air yang tidak mencukupi, kesuburan tanah yang redah, varietas tanaman yang kurang respon terhadap lingkungan dan pemupukan, sistem pengelolaan tanaman yang kurang baik, dan perkembangan hama dan penyakit yang semakin meluas. Selain itu terjadi pengurangan lahan sawah subur akibat konversi lahan untuk kepentingan selain pertanian, seperti pembangunan perumahan, pabrik dan jalan tol. Sehingga peningkatan produksi beras untuk mengimbangi peningkatan permintaan akan sulit terpenuhi apabila hanya berfokus pada lahan sawah, sehingga diharapkan pula sumbangan pemenuhan beras dari lahan kering dengan membudidayakan padi gogo.

Indonesia memiliki lahan kering sekitar 148 juta ha (Kementan 2014). 69\% total luas wilayah Sulawesi Tenggara yang mencapai 3.814 .000 ha, diantaranya adalah lahan kering (BPS, 2016) sehingga dinilai sangat berpotensi untuk pengembangan budidaya padi gogo. Selain memiliki lahan yang luas, Sulawesi Tenggara juga memiliki banyak plasma nutfah padi gogo lokal yang secara tradisional telah dibudidayakan oleh masyarakat petani di Sulawesi Tenggara (Wahab, 2014). Petani umumnya masih lebih menyukai padi gogo lokal dibandingkan dengan padi gogo unggul introduksi untuk budidaya. Hal ini disebabkan karena faktor aksestabilitas untuk mendapatkan benih padi gogo yang unggul sulit di dapatkan, karena kurangnya ketersediaan benih dan minat penangkar dalam memproduksi benih padi gogo yang unggul tersebut, selain itu faktor rasa dari beras yang dihasilkan (padi aromatik), meskipun berproduksi rendah, namun memiliki nilai ekonomi tinggi terutama pada masyarakat berkehidupan mapan (Seno et al., 2011).

Kendala pengembangan padi gogo yaitu, karena masalah kesuburan tanah yang rendah dan ketersedian air yang terbatas. Lahan kering di Sulawesi Tenggara didominasi oleh tanah ultisol dengan tingkat kemasaman tinggi serta banyak mengandung besi dan aluminium, curah hujan yang rendah dan distribusi tidak merata, sehingga membatasi musim tanam. Usaha untuk meningkatkan pemanfaatan potensi lahan kering guna pencapaian produksi tinggi dengan kualitas beras padi gogo maka sangat perlu dilakukan pemupukan dengan tetap menjaga kelestarian lingkungan.
Penggunaan pupuk organik telah lama dikenal dalam perbaikan kesuburan tanah pertanian. Pengaruh pemberian pupuk organik bahkan dapat dirasakan sampai beberapa tahun setelah pemberian. Pemberian pupuk organik dapat memberikan berbagai keuntungan diantaranya peningkatan kesuburan, perbaikan struktur tanah, kemampuan menyimpan air dalam tanah, peningkatan kandungan bahan organik dan mengurangi penggunaan pupuk kimia (Andrews, et al. 2006). Residu pupuk organik juga dapat meningkatkan produktivitas serta kesuburan tanah (Eghball, at al. 2004).

Ampas sagu adalah salah satu bahan organik yang dapat dijadikan bokashi untuk digunakan sebagai pupuk pada lahan pertanian. Ketersediaan ampas sagu sangat melimpah dan hanya menjadi limbah pertanian yang tidak dimanfaatkan oleh masyarakat, karena masih sangat terbatasnya informasi mengenai kandungan unsur hara yang terdapat pada ampas sagu. Menurut Syakir (2009), bokashi ampas sagu memiliki kandungan unsur hara makro dan mikro, diantaranya Nitrogen, Phospat, Kalium, kalsium dan Magnesium. Mubandono (2007) melaporkan bokashi ampas sagu dapat menjadikan tanah menjadi gembur, menyerap air dan mampu mempertahankannya dalam waktu yang lama, sebagai media tempat berkembangnya mikroba tanah yang berguna dalam proses pelapukan bahan-bahan organik dalam tanah, memberikan unsur hara yang cukup bagi tanaman untuk proses pertumbuhan dan membantu dalam roses pertumbuhan akar tanaman, sehingga tanaman dapat tumbuh dengan baik dan meningkatkan produksi hasil panen tanaman. Namun, demikian pupuk organik (bokashi ampas sagu) juga memiliki kelemahan, yaitu lambat untuk terurai, sehingga pelepasan haranya lebih lambat Pula (Sarawa et al., 2014).

Sehubungan dengan hal tersebut maka perlu adanya penambahan mikroorganisme yang dapat mempercepat proses dekomposisi bahan organik sehingga tersedia bagi kebutuhan tanaman (Nasir, 2005). Salah satu mikroorganisme fungsional yang dikenal luas sebagai pupuk biologis tanah adalah jamur Trichoderma sp. Trichoderma sp. juga dapat memberikan pengaruh positif terhadap perakaran tanaman, pertumbuhan tanaman dan hasil produksi tanaman (Hastuti, $d k k$., 2009). Keberadaan Trichoderma pada media tumbuh tanaman, selain sebagai biokontrol, juga ternyata mampu meningkatkan ketahanan tanaman terhadap cekaman kekeringan (Chuanjin et al. 2014). Trichoderma juga mampu menghambat pertumbuhan dan perkembangan patogen, terutama pathogen indigenous dan telah terbukti pada beberapa tempat (Sarawa, et al., 2014). 
Mengingat kelemahan pupuk organik (bokashi ampas sagu) yang lambat terurai, maka pemberian Trichoderma sp.diharapkan mampu mendekomposisi bahan organik sehingga unsur-unsur hara yang dibutuhkan oleh tanaman dapat tersedia dalam waktu yang relative lebih cepat dari biasanya. Berdasarkan uraian tersebut maka dianggap sangat perlu dilakukannya penelitian dengan judul "Pertumbuhan padi gogo lokal pada lahan ultisol yang diberi bokashi ampas sagu dan Trichoderma".

\section{METODE PENELITIAN}

Penelitian dilaksanakan di Kebun Percobaan II Unit Lahan Kering dan Laboratorium Agronomi Fakultas Pertanian Universitas Halu Oleo Kendari mulai dari bulan Januari 2018 sampai bulan Agustus
2018. Bahan yang digunakan dalam penelitian adalah benih padi gogo lokal (PaebiuTamalaki) asal Sulawesi Tenggara, bokashi ampas sagu dan Trikoderma. Alat yang digunakan adalah parang, cangkul, skopang, timbangan dan timbangan analitik, gembor, mistar, kamera dan alat tulis-menulis. Variabel yang diamati meliputi: Tinggi tanaman (cm), Jumlah daun (helei) dan Luas daun total $\left(\mathrm{cm}^{2}\right)$.

\section{HASIL}

Rekapitulasi hasil analisis sidik ragam pertumbuhan padi gogo lokal pada tanah ultisol yang diberi bokashi ampas sagu dan Trichoderma terjadi interaksi nyata pada variabel pengamatan tinggi tanaman dan jumlah daun umur 70 hst (Tabel 1).

Tabel 1. Rekapitulasi analisis sidik ragam pertumbuhan padi gogo lokal pada lahan ultisol yang diberi bokashi ampas sagu dan Trichoderma

\begin{tabular}{|c|c|c|c|c|}
\hline \multirow{2}{*}{ No. } & \multirow{2}{*}{ Variabel Pengamatan } & \multicolumn{3}{|c|}{ Uji F Perlakuan } \\
\hline & & Trichoderma $(\mathrm{T})$ & Bokashi (B) & $\mathrm{T} * \mathrm{~B}$ \\
\hline \multirow{4}{*}{1} & Tinggi tanaman $28 \mathrm{hst}$ & tn & tn & tn \\
\hline & Tinggi tanaman $42 \mathrm{hst}$ & tn & tn & tn \\
\hline & Tinggi tanaman 56 hst & tn & tn & tn \\
\hline & Tinggi tanaman $70 \mathrm{hst}$ & tn & $* *$ & tn \\
\hline \multirow{4}{*}{2} & Jumlah daun 28 hst & tn & tn & tn \\
\hline & Jumlah daun 42 hst & tn & tn & $\operatorname{tn}$ \\
\hline & Jumlah daun 56 hst & tn & tn & $\operatorname{tn}$ \\
\hline & Jumlah daun 70 hst & tn & $*$ & tn \\
\hline \multirow{4}{*}{3} & Luas daun total $28 \mathrm{hst}$ & tn & tn & $\operatorname{tn}$ \\
\hline & Luas daun total $42 \mathrm{hst}$ & tn & tn & $\operatorname{tn}$ \\
\hline & Luas daun total $56 \mathrm{hst}$ & tn & tn & $\operatorname{tn}$ \\
\hline & Luas daun total $70 \mathrm{hst}$ & tn & tn & tn \\
\hline 4 & Laju tumbuh absolute & ** & ** & tn \\
\hline
\end{tabular}

\section{Tinggi tanaman}

Tabel 2. Pertumbuhan tinggi tanaman 70 hst padi gogo lokal yang diberi bokashi ampas sagu dan Trichoderma

\begin{tabular}{|c|c|c|c|c|c|c|c|}
\hline \multirow{2}{*}{ Bokasi } & \multicolumn{5}{|c|}{ Trichoderma } & \multirow{2}{*}{ Rerata } & \multirow{2}{*}{$\begin{array}{c}\text { UJBD } \\
\text { (Bokashi } \\
\alpha=0,05\end{array}$} \\
\hline & T0 & $\mathrm{T} 1$ & $\mathrm{~T} 2$ & T3 & $\mathrm{T} 4$ & & \\
\hline B0 & 93.63 & 114.48 & 97.21 & 92.85 & 114.41 & $102.52 \mathrm{~b}$ & $2=1.88$ \\
\hline $\mathrm{B} 1$ & 100.19 & 113.21 & 84.43 & 115.45 & 110.58 & $104.77 \mathrm{~b}$ & $3=1.98$ \\
\hline B2 & 92.10 & 110.65 & 98.58 & 120.08 & 117.27 & $107.73 \mathrm{~b}$ & $4=2.04$ \\
\hline B3 & 114.31 & 113.75 & 100.09 & 106.18 & 113.32 & $109.53 \mathrm{a}$ & $5=2.08$ \\
\hline B4 & 103.50 & 103.59 & 97.20 & 121.98 & 120.33 & $109.32 \mathrm{a}$ & \\
\hline
\end{tabular}

Keterangan : Angka-angka yang diikuti oleh huruf (a-b) yang tidak sama pada kolom dan baris yang sama berbeda nyata berdasarkan UJBD pada taraf kepercayaan $95 \%$.

Tabel 2 menunjukkan pengaruh perlakuan mandiri bokashi ampas sagu terhadap tinggi tanaman yaitu, tinggi tanaman tertinggi terdapat pada dosis B4 $\left(48\right.$ ton $\left.^{-1}{ }^{-1}\right)$ tidak berbeda nyata dengan dosis B3 (36 ton $\mathrm{ha}^{-1}$ ) dan berbeda nyata pada dosis lainnya.
Perlakuan mandiri bokashi ampas sagu dosis B1 (12 ton $\mathrm{ha}^{-1}$ ) tidak berbeda nyata dengan dosis B2 (24 ton $\mathrm{ha}^{-1}$ ) dan B0 (tanpa pemberian bokasi). Dinamika tinggi tanaman dapat dilihat pada Gambar 2a- 2e. 


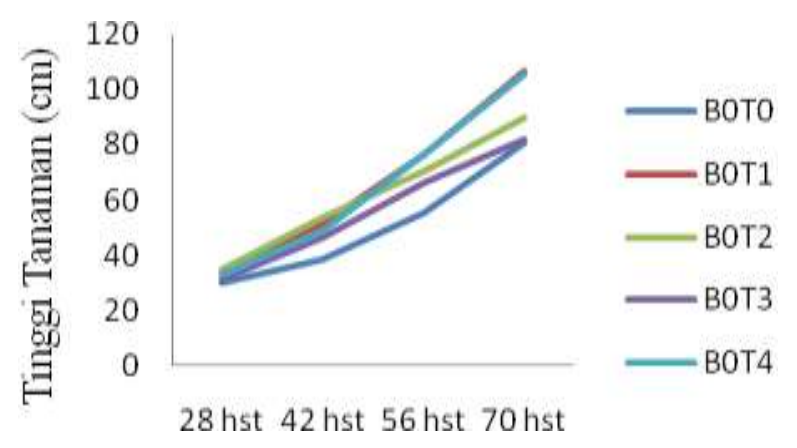

Gambar 2a. Dinamika pertumbuhan tinggi tanaman padi yang tidak diberi bokashi (B0) pada umur 28-70 hst

Gambar 2a terlihat bahwa perlakuan B0T2 memberikan tinggi tanaman tertinggi sejak umur 2842 hst, sedangkan pada perlakuan B0T4 dan B0T1 menunjukkan pertumbuhan tertinggi yang lebih besar pada umur 56 dan 70 hst, walaupun demikian pada awal pertumbuhan semua perlakuan tidak memperlihatkan pengaruh yang berbeda antara satu dengan yang lainnya.

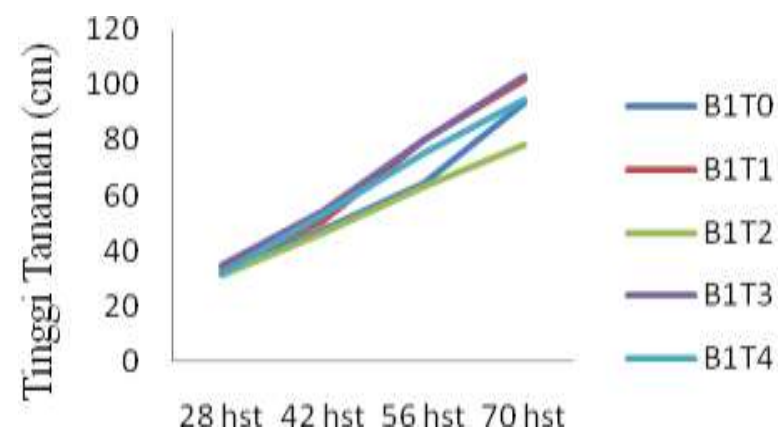

Gambar 2b. Dinamika pertumbuhan tinggi tanaman padi yang diberi bokashi 12 ton ha- ${ }^{1}$ (B1) pada umur 28-70 hst

Gambar 2b perlakuan B1T1 dan B1T3 memperlihatkan tinggi tanaman yang pesat sejak umur 28-70 hst, walaupun pada umur 56 hst perlakuan B1T1 sempat mengalami penurunan tinggi tanaman dibanding B1T4, walaupun tidak memperlihatkan pengaruh yang berbeda antara satu dengan yang lainnya, sehingga pada umur 70 hst pengaruh uji hampir sama dengan Kontrol (B0T0).

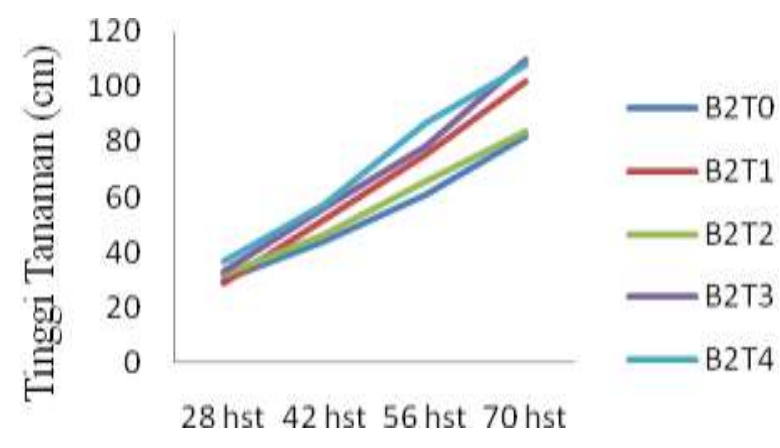

Gambar 2c. Dinamika pertumbuhan tinggi tanaman padi yang diberi bokashi 24 ton ha- ${ }^{1}$ (B2) pada umur 28-70 hst

Gambar 2c perlakuan B2T4 dan B2T3 memperlihatkan tinggi tanaman yang pesat sejak umur 28-70 hst. Perlakuan B2T3 mengalami pertambahan tinggi tanaman yang lebih besar dibanding B2T4 pada umur 70 hst.

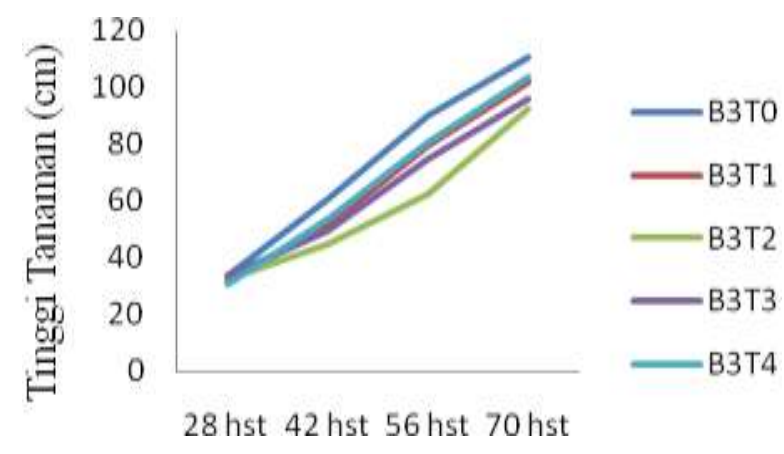

Gambar 2d. Dinamika pertumbuhan tinggi tanaman padi yang diberi bokashi 36 ton ha- ${ }^{1}$ (B3) pada umur 28-70 hst

Gambar 2d terlihat bahwa perlakuan B3T0 memberikan tinggi tanaman tertinggi sejak umur 2870 hst dibanding perlakuan lainnya, walaupun pertumbuhan semua perlakuan tidak memperlihatkan pengaruh yang berbeda antara satu dengan yang lainnya.

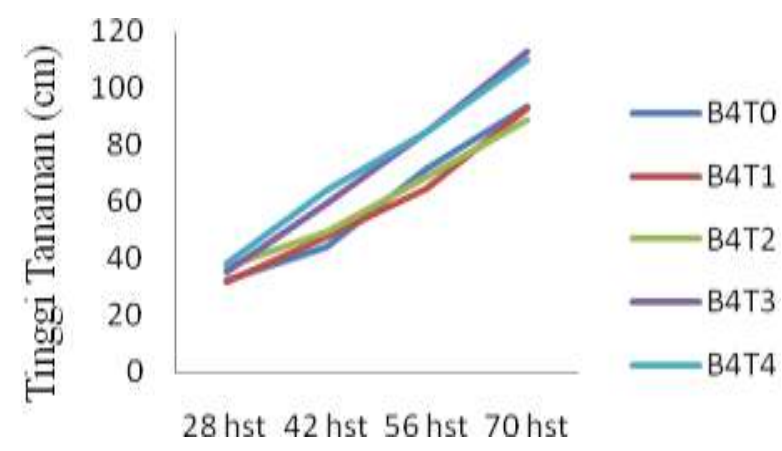

Gambar 2e. Dinamika pertumbuhan tinggi tanaman padi yang diberi bokashi 48 ton ha- ${ }^{1}$ (B4) pada umur 28-70 hst 
Gambar 2e terlihat bahwa perlakuan B4T4 memberikan tinggi tanaman tertinggi sejak umur 2842 hst, sedangkan pada perlakuan B4T3 menunjukkan pertumbuhan tertinggi yang lebih besar pada umur 56 dan 70 hst.

\section{Jumlah daun}

Tabel 3. Pertumbuhan jumlah daun (helai) padi gogo lokal yang diberi bokashi ampas sagu dan Trichoderma

\begin{tabular}{cccccccc}
\hline \multirow{2}{*}{. Bokasi } & \multicolumn{5}{c}{ Trichoderma } & Rerata & $\begin{array}{c}\text { UJBD } \\
\text { (Bokashi) } \\
\end{array}$ \\
\cline { 2 - 6 } & T0 & T1 & T2 & T3 & T4 & & 05 \\
\hline B0 & 7.73 & 7.87 & 7.73 & 7.53 & 8.00 & $7.77 \mathrm{~b}$ & $2=0.043079$ \\
B1 & 7.60 & 8.13 & 7.60 & 8.07 & 8.13 & $7.91 \mathrm{a}$ & $3=0.045342$ \\
B2 & 7.67 & 8.00 & 7.33 & 7.93 & 7.67 & $7.72 \mathrm{~b}$ & $4=0.047112$ \\
B3 & 8.00 & 7.67 & 7.60 & 7.87 & 7.93 & $7.81 \mathrm{a}$ & $5=0.047755$ \\
B4 & 7.87 & 7.53 & 7.67 & 7.93 & 8.47 & $7.89 \mathrm{a}$ & \\
\hline
\end{tabular}

Keterangan : Angka-angka yang diikuti oleh huruf (a-b) yang tidak sama pada kolom dan baris yang sama berbeda nyata berdasarkan UJBD pada taraf kepercayaan $95 \%$.

Tabel 3 menunjukkan pengaruh perlakuan mandiri bokashi ampas sagu terhadap jumlah daun yaitu, jumlah daun tertinggi terdapat pada dosis B4 (48 ton ha ${ }^{-1}$ ) tidak berbeda nyata dengan dosis B3 (36 ton $\mathrm{ha}^{-1}$ ) dan B1 (12 ton $\mathrm{ha}^{-1}$ ) namun berbeda nyata dengan dosis lainnya. Pengaruh mandiri bokashi ampas sagu dosis B0 (tanpa pemberian bokasi) tidak berbeda nyata dengan dosis B2 (24 ton $\left.\mathrm{ha}^{-1}\right)$. Dinamika jumlah daun dapat dilihat pada Gambar 3a$3 \mathrm{e}$

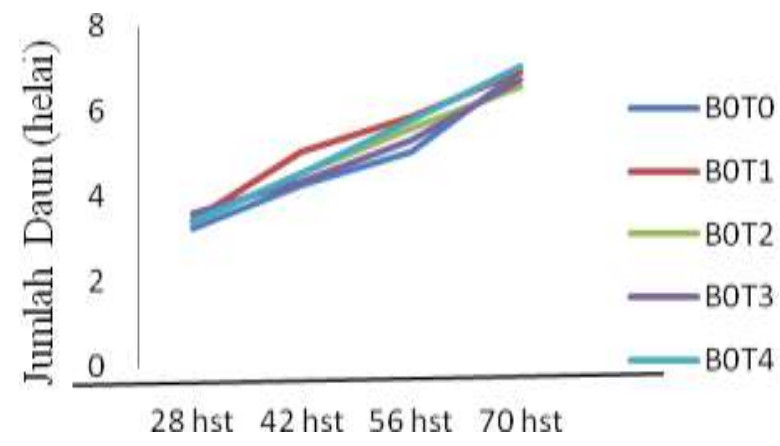

Gambar 3a. Dinamika pertumbuhan jumlah daun tanaman padi yang tidak diberi bokashi (B0) pada umur 28-70 hst

Gambar 3a terlihat pertambahan jumlah daun pada awal pertumbuhan umur 28-56 hst tidak menunjukkan perbedaan, walaupun demikian dapat terlihat jumlah daun perlakuan B0T3 umur 28 hst lebih banyak dan umur 42-70 hst perlakuan B0T1 meningkat dibanding B0T3 dan pada umur 70 hst perlakuan B0T4 meningkat lebih pesat.

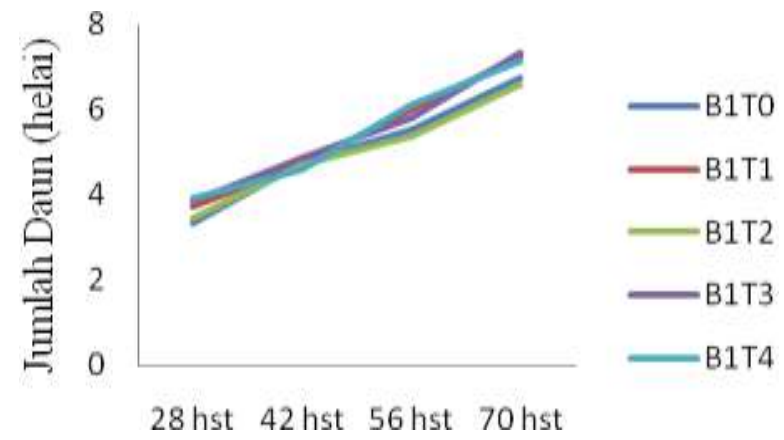

Gambar 3b. Dinamika pertumbuhan jumlah daun tanaman padi yang diberi bokashi 12 to ha- ${ }^{1}$ (B1) pada umur 28-70 hst

Gambar 3b terlihat bahwa perlakuan B1T4 memberikan jumlah daun tanaman tertinggi umur 28 dan 56 hst, sedangkan pada perlakuan B1T3 menunjukkan pertumbuhan jumlah daun tertinggi yang lebih besar pada umur 42 dan 70 hst, walaupun demikian pada awal pertumbuhan semua perlakuan tidak memperlihatkan pengaruh yang berbeda antara satu dengan yang lainnya.

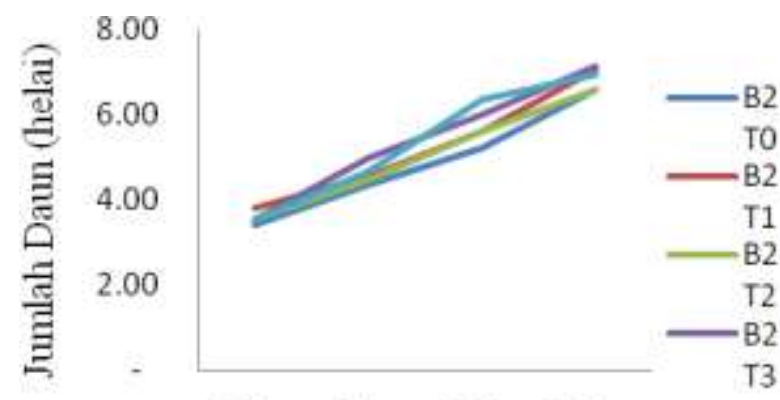

28 hst 42 hst 56 hst 70 hst 
Gambar 3c. Dinamika pertumbuhan jumlah daun tanaman padi yang diberi bokashi 24 to ha- ${ }^{1}$ (B2) pada umur 28-70 hst

Gambar $3 c$ terlihat pertambahan jumlah daun pada awal pertumbuhan umur 28 hst tidak menunjukkan perbedaan, walaupun demikian dapat terlihat jumlah daun perlakuan B2T1 umur 28 hst lebih banyak, walaupun demikian peningkatan jumlah daun tertingi terlihat pada perlakuan B2T3 umur 56 dan 70 hst.

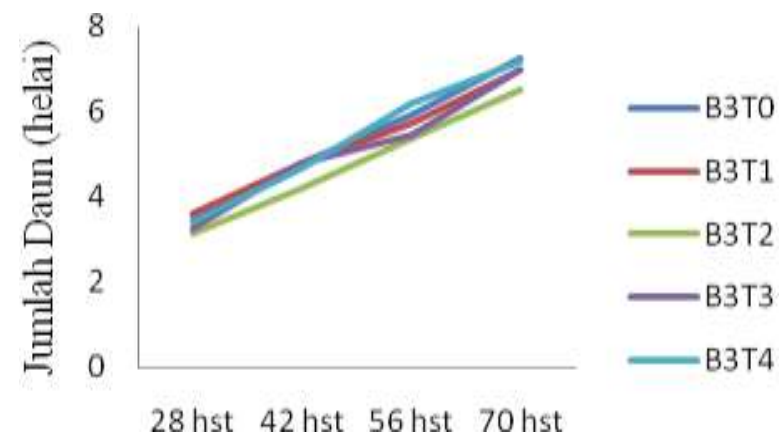

Gambar 3d. Dinamika pertumbuhan jumlah daun tanaman padi yang diberi bokashi 36 to ha- ${ }^{1}$ (B3) pada umur 28-70 hst

Gambar 3d terlihat bahwa perlakuan B3T1 memberikan jumlah daun tanaman tertinggi umur 2842 hst dan perlakuan B3T4 mengalami peningkatan jumlah daum umur 56 dan 70 hst, walaupun demikian pada awal pertumbuhan semua perlakuan tidak memperlihatkan pengaruh yang berbeda antara satu dengan yang lainnya

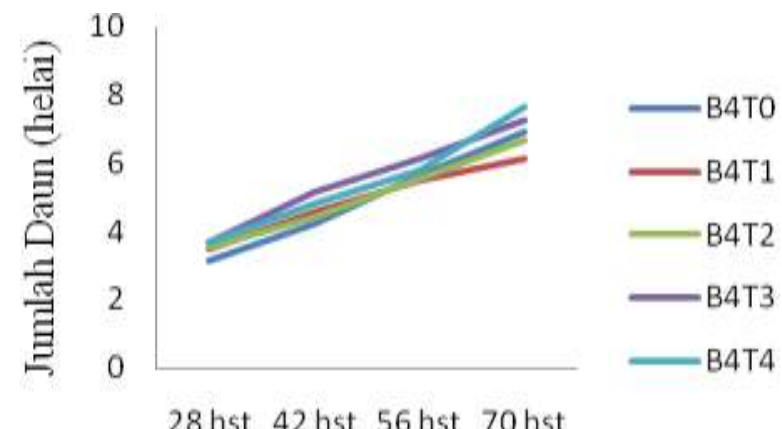

Gambar 3e. Dinamika pertumbuhan jumlah daun tanaman padi yang diberi bokashi 48 to ha- ${ }^{1}$ (B4) pada umur 28-70 hst

Gambar 3e terlihat bahwa perlakuan B4T3 memberikan jumlah daun tanaman tertinggi umur 2856 hst yang diikuti perlakuan B4T4. Umur 70 hst jumlah daun B4T4 meningkat lebih tinggi dibanding B4T3, walaupun demikian pada awal pertumbuhan semua perlakuan tidak memperlihatkan pengaruh yang berbeda antara satu dengan yang lainnya.

\section{Luas daun total}

Diagram luas daun total dapat dilihat pada Gambar 4a-4e.

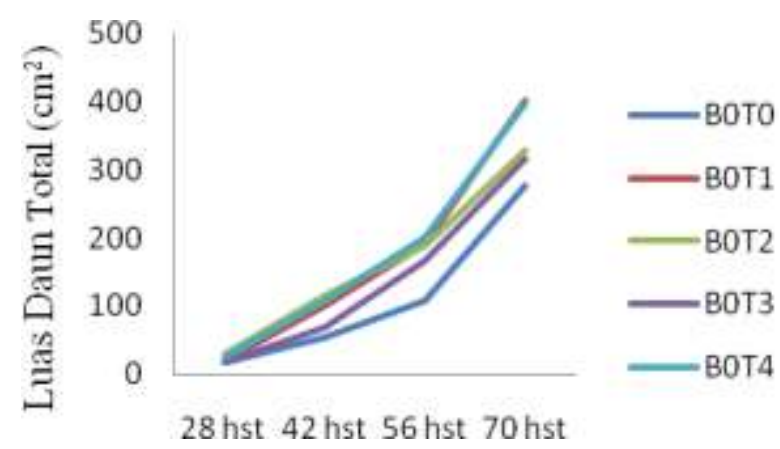

Gambar 4a. Dinamika pertumbuhan luas daun total tanaman padi yang tidak diberi bokashi (B0) pada umur 28-70 hst

Gambar 4a terlihat bahwa luas daun total perlakuan B0T2 tertinggi pada umur 28-70 hst meskiun sempat mengalami penurunan pada umur 56 hst dibanding perlakuan B0T4, walaupun demikian pertambahan luas daun total semua perlakuan tidak memperlihatkan pengaruh yang berbeda antara satu dengan yang lainnya.

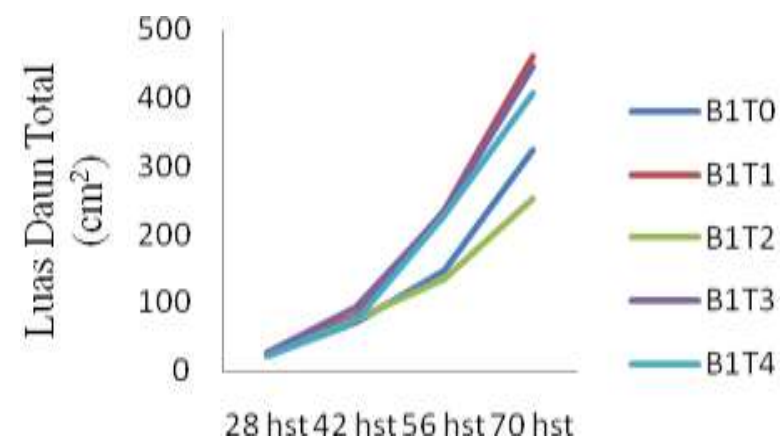

Gambar 4b. Dinamika pertumbuhan luas daun total tanaman padi yang diberi bokashi 12 to ha- ${ }^{1}$ (B1) pada umur 28-70 hst

Gambar 4b terlihat perlakuan B1T3 memberikan luas daun total tertinggi pada umur 2842 hst dan luas daun perlakuan B1T1 meningkat pada umur 56 hst dan peningkatan luas daun total umur 70 hst terjadi pada perlakuan B1T0, walaupun demikian pertambahan luas daun total semua perlakuan tidak memperlihatkan pengaruh yang berbeda antara satu dengan yang lainnya. 


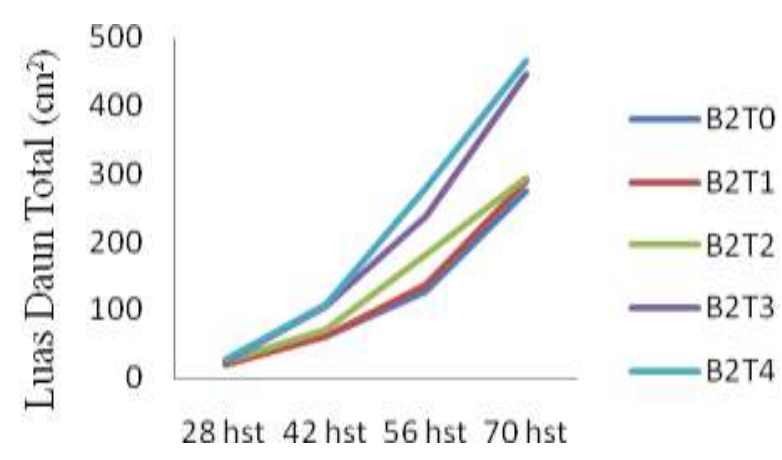

Gambar 3c. Dinamika pertumbuhan luas daun total tanaman padi yang diberi bokashi 24 to ha- ${ }^{1}$ (B2) pada umur 28-70 hst

Gambar 4c terlihat bahwa luas daun total perlakuan B2T4 mengalami peningkatan secara konsisten mulai umur 28-70 hst, walaupun demikian pertambahan luas daun total semua perlakuan tidak memperlihatkan pengaruh yang berbeda antara satu dengan yang lainnya.

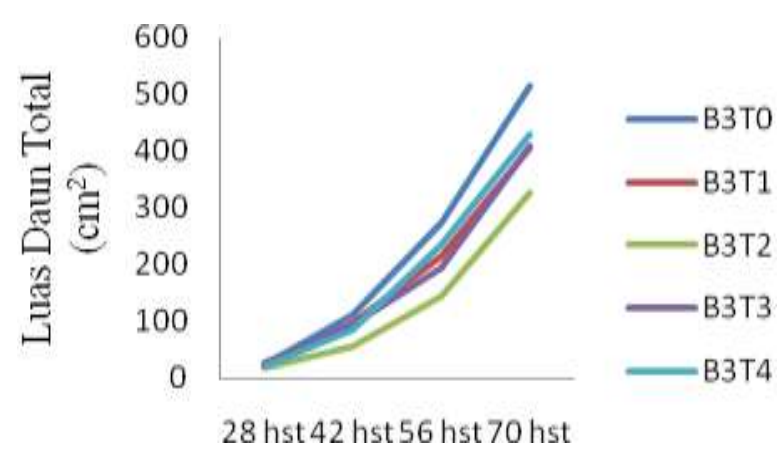

Gambar 3d. Dinamika pertumbuhan luas daun total tanaman padi yang diberi bokashi 36 to ha- ${ }^{1}$ (B3) pada umur 28-70 hst

Gambar 4d terlihat bahwa luas daun total perlakuan B3T3 tertinggi pada umur $28 \mathrm{hst}$. Luas daun total perlakuan B3T0 meningkat pada umur 4256 hst dan luas daun perlakuan B3T4 meningkat pada umur 70 hst, walaupun demikian pertambahan luas daun total semua perlakuan tidak memperlihatkan pengaruh yang berbeda antara satu dengan yang lainnya.

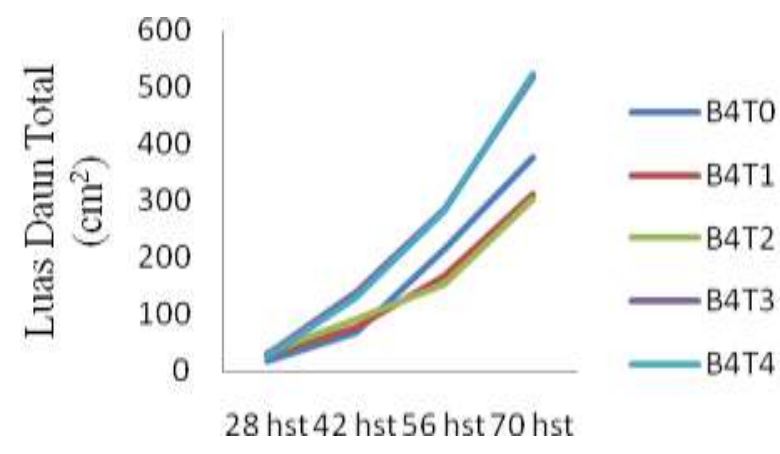

Gambar 3e. Dinamika pertumbuhan luas daun total tanaman padi yang diberi bokashi 48 to ha- ${ }^{1}$ (B4) pada umur 28-70 hst

Gambar 4e terlihat bahwa luas daun total perlakuan T1 tertinggi pada umur 28 hst. Luas daun total perlakuan B4T3 meningkat pada umur 42-56 hst dan luas daun perlakuan B4T4 meningkat pada umur 70 hst, walaupun demikian pertambahan luas daun total semua perlakuan tidak memperlihatkan pengaruh yang berbeda antara satu dengan yang lainnya.

Tabel 4. Pertumbuhan Laju Tumbuh Absolute padi gogo lokal yang diberi bokashi ampas sagu dan Trichoderma

\begin{tabular}{|c|c|c|c|c|c|c|c|}
\hline \multirow[b]{2}{*}{ Bokasi } & \multicolumn{5}{|c|}{ Trichoderma } & \multirow[b]{2}{*}{ Rerata } & \multirow{2}{*}{$\begin{array}{c}\text { UJBD } \\
\text { (Bokashi) } \\
\alpha=0,05\end{array}$} \\
\hline & T0 & $\mathrm{T} 1$ & $\mathrm{~T} 2$ & $\mathrm{~T} 3$ & $\mathrm{~T} 4$ & & \\
\hline B0 & 1.56 & 2.69 & 2.67 & 2.89 & 3.35 & $2.63 \mathrm{c}$ & $2=0.376$ \\
\hline $\mathrm{B} 1$ & 2.05 & 2.42 & 1.90 & 3.30 & 3.34 & $2.60 \mathrm{c}$ & $3=0.396$ \\
\hline B2 & 1.82 & 2.48 & 2.68 & 3.97 & 3.47 & $2.88 \mathrm{~b}$ & $4=0.408$ \\
\hline B3 & 3.37 & 2.97 & 2.03 & 3.07 & 2.96 & $2.88 \mathrm{~b}$ & $5=0.417$ \\
\hline B4 & 3.04 & 3.09 & 3.08 & 3.62 & 4.98 & $3.56 \mathrm{a}$ & \\
\hline Rerata & $2.37 \mathrm{~b}$ & $2.73 \mathrm{~b}$ & $2.47 \mathrm{~b}$ & $3.37 \mathrm{a}$ & $3.62 \mathrm{a}$ & & \\
\hline $\begin{array}{l}\text { UJBD } \\
\text { (Trichoderma) } \\
\alpha=0,05\end{array}$ & $2=0.38$ & $3=0.40$ & $4=0.41$ & $5=0.42$ & & & \\
\hline
\end{tabular}

Keterangan : Angka-angka yang diikuti oleh huruf yang tidak sama pada kolom dan baris yang sama berbeda nyata berdasarkan UJBD pada taraf kepercayaan $95 \%$.

Tabel 4 menunjukkan laju tumbuh absolute tertinggi pada pengaruh perlakuan mandiri bokashi ampas sagu terdapat pada dosis B4 (48 ton ha ${ }^{-1}$ ) berbeda nyata dengan dosis lainnya. Perlakuan mandiri 
bokashi dosis B3 (36 ton ha ${ }^{-1}$ ) tidak berbeda nyata dengan dosis B2 (24 ton ha $\left.{ }^{-1}\right)$ dan perlakuan mandiri bokashi dosis B1 (12 ton ha ${ }^{-1}$ ) tidak berbeda nyata dengan dosis B0 (tanpa pemberian bokasi). Adapun laju tumbuh absolute tertinggi pada pengaruh mandiri Trichoderma terdapat pada dosis T3 $\left(3,2\right.$ ton $\left.\mathrm{ha}^{-1}\right)$ tidak berbeda nyata dengan perlakuan Trichoderma pada dosis T4 $\left(6,8\right.$ ton $\left.\mathrm{ha}^{-1}\right)$ namun berbeda nyata pada perlakuan Trichoderma dosis T0 (tanpa Trichoderma), T1 (1,6 ton ha $\left.{ }^{-1}\right)$ dan T2 (3,2 ton ha $\left.{ }^{-1}\right)$.

\section{PEMBAHASAN}

Pupuk bokashi ampas sagu merupakan bahan organik yang dapat menjadikan lahan yang miskin unsur hara menjadi lahan yan produktif ditambah proses pembuatan bokashi ampas sagu difermentasikan menggunakan mikroorganisme sehingga dapat melalui proses alamiah. Penambahan Trichoderma pada pupuk bokashi ampas sagu mempercepat proses fermentasi dan memperbaiki kualitas bokashi yang dihasilkan karena Trichoderma menghasilkan enzim celobiohidrolase, endoglikonase dan glokosidase yang bekerja secara sinergis sehingga proses penguraian dapat berlangsung lebih cepat dan intensif (Salma dan Gunarto, 1996). Peran Trichoderma selain sebagai pengurai juga dapat berfungsi sebagai agen hayati dan stimulator pertumbuhan tanaman, sehingga Trichoderma sp. memberikan pengaruh positif terhadap perakaran tanaman, pertumbuhan tanaman dan hasil tanaman (Maria, 2016).

Hasil perlakuan mandiri ampas sagu memberi pengaruh yang sangat nyata dan mampu meningkatkan tinggi tanaman, jumlah daun dan laju tumbuh absolute. Perlakuan mandiri bokashi ampas sagu pada dosis 48 ton ha $^{-1}$ memperlihatkan tinggi tanaman yang maksimal yaitu $121,98 \mathrm{~cm}$ tidak berbeda nyata dengan dosis 36 ton ha ${ }^{-1}(113,32 \mathrm{~cm})$. Pemberian mandiri ampas sagu pada dosis 48 ton ha ${ }^{-1}$ juga meningkatkan jumlah daun dan luas daun tanaman. Hal ini menunjukkan pemberian bokashi ampas sagu tersedia bagi tanaman sehingga membantu tanaman dalam meningkatkan laju fotosintesis karena tercukupinya hara yang diserap. Semakin banyak jumlah daun maka semakin laju tanaman melakukan proses fotosintesis, maka akan semakin memacu laju tumbuh absolute dan pertumbahan tinggi tanaman. Hal ini sejalan dengan pendapat Nasution (2009), menyatakan bahwa tanaman akan dapat tumbuh subur apabila unsur hara dalam keadaan tersedia dalam tanah, karena pertumbuhan tanaman tergantung dari unsur hara yang diperoleh dari tanah serta dipengaruhi oleh penambahan unsur hara yang diperoleh dari pemberian pupuk organik. Hal ini diperkuat dengan pendapat Masno dan Sigit (2001), pengaruh pupuk organik dengan dosis tinggi pada penggunaannya akan menyediakan unsur hara bagi tanaman seperti unsur hara makro (N, P dan $\mathrm{K}$ ).

Pertambahan tinggi tanaman berkaitan erat dengan unsur hara makro, salah satunya adalah unsur Nitrogen. Unsur Nitrogen dibutuhkan tanaman untuk pembentukan klorofil dan protein. Menurut Rafi (2013) unsur Nitrogen berfungsi sebagai penyusun dari banyak senyawa esensial bagi tumbuhan, misalnya asam-asam amino. Semakin banyak unsur hara Nitrogen yang diserap tanaman akan meningkatkan pertumbuhan dan perkembangan tanaman. Menurut Hakim et al. (1986) pupuk organik mempunyai kelebihan secara fisik dapat menggemburkan konsistensi atau kepadatan tanah, membantu melarutkan unsur-unsur, mengurangi kebutuhan pupuk dengan menciptakan sistem aerasi tanah, meningkatkan daya simpan air dan memperbaiki struktur tanah.

\section{SIMPULAN}

1. Perlakuan bokashi ampas sagu dan Trichoderma memberikan pengaruh nyata terhadap variabel pengamatan tinggi tanaman dan jumlah daun umur 70 hst dan juga laju tumbuh absolute.

2. Dosis terbaik bokashi ampas sagu dan Trichoderma yaitu B3T3 (36 ton ha ${ }^{-1}$ bokashi dan 4,8 ton ha ${ }^{-1}$ Trichoderma).

\section{DAFTAR PUSTAKA}

Andrews, Mc., Gina M., Liebman, Mtt., Cambardella, Cynthia A, Richard, Tom, L. 2006. Residual Effects of Composted and Fresh Soil Swine (Suscrofa L.) Manand ure (Glicine max (L.) Merr) Growth and Yield. Agron. J. 98.4 : 873-882

Badan Pusat Statistik Sulawesi Tenggara. 2016. Sulawesi Tenggara dalam Angka. Badan Pusat Statistik. Profinsi Sulawesi Tenggara.

Chuanjin, Yu; Fan Liliwu; Qiong, Fu Kehe, Gao, dan Shigang. 2014. Biological Role of Trichoderma harzianum-Derived PlateletActivating Factor Acetylhidrolase (PAF-AH) on StressResponse and Antagonism. Plos One 9.6

Eghaball, Bahman, Ginting, dan Daniel, 2004. Residual effects of Manure and Compost Application on Corn Production and Soil Properties. Agron. J. 96.2: 442-447

Hakim, N., M.Y. Nyakpa., A.M. Lubis.,S.G. Nugroho., M.R. Saul., M.A. Diha., Go Ban Hong., H. Bailey. 1986. Dasar-Dasar Ilmu Tanah. Universitas Lampung. 


\section{J. Berkala Penelitian Agronomi 7 (1) : 7 - 15 (2019)}

Kementrian Pertanian. 2014. Statistika Lahan Pertanian 2009-2013. Kementrian Pertanian. Jakarta.

Murbandono. 2007. Membuat Kompos. Jakarta.Penebar Swadaya.

Nasution, E. 2009. Aplikasi Beberapa Tandan Kosong Kelapa Sawit Terhadap Pertumbuhan Bibit Jarak Pagar (Jathropa curcas). Pekanbaru : Fakultas Pertanian. Universitas Riau.

Rafi. 2013. Pengaruh Pemberian Kompos Tinja Terhadap Pertumbuhan dan Produksi Tanaman Kedelai (Glycine max (L) merril). Fakultas Pertanian. Universitas Riau.

Salma, S. dan L. Gunarto. 1996. Aktivitas Trichoderma dalam Perombakan Selulosa. Penelitian Pertanian Tanaman Pangan.

Sarawa, gusnawati dan sartika. 2014.Efek Residu Pupuk Kandang dan Trichoderma terhadap Pertumbuhan dan Produksi Tanaman Kedelai (Glycine $\max$ L.). Agriplus, Volume 24 Nomor : 02 Mei 2014, ISSN 0854-0128

Seno, D.S.H., at al. 2011. Identifikasi Gen Aroma Pada Progeni-Progeni Backcross antara Varietas Ciherang dengan Pandan Wangi. Jurnal llmu Pertanian Indonesia. Hal. 136141.

Wahab. 2014. Karakteristik Vegetatif Enam Kultivar Padi Gogo Lokal Sulawesi Tenggara. Prosiding Seminar Nasional "Inovasi Teknologi Pertanian Spesifik Lokasi”. Banjarbaru. 